\title{
Akciğer Kanseri Semptom Taramasının Sigara Bıraktırmadaki Rolü*
}

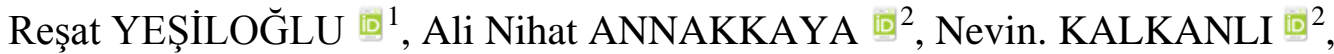 \\ Naciye KARATAŞ ${ }^{3}$, Öner BALBAY 國 ${ }^{2}$, Peri ARBAK ${ }^{2}$
}

ÖZ

Amaç: Bu çalışmada Düzce ilinde 30 yaş ve üzeri sigara içenlerde akciğer kanseri semptom taramasının sigara bırakmadaki rolü araştırıldı.

Gereç ve Yöntemler: Randomize 700 hane seçilerek 30 yaş üzeri sigara anamnezi olan 500 olgu çalışmaya alındı. Olguların sigara alışkanlıkları ve akciğer kanseri semptomları bir anket formuyla yüz yüze görüşmeyle sorgulandı. Sigaranın akciğer kanseri için önemli bir risk faktörü olduğu vurgulandı. Halen aktif sigara içen 474 olgunun 353 'üne 6 ay sonra telefonla sigara alışkanlıkları yeniden sorgulandı.

Bulgular: Toplam 353 sigara içen olgunun 32'si $(\% 9,1)$ kadın, 321'i $(\% 90,9)$ erkekti. Yaş ortalaması $46 \pm 9$ olan olguların, ortalama $36 \pm 24$ paket-yıl sigara anamnezi vard1. 130'u $(\% 36,8)$ sigarayı bırakmayı düşünüyordu ve 65 'i $(\% 18,4)$ sigarayı bırakmayı denemişti. 6 ay sonraki kontrolde 17 olgu $(\% 4,8)$ sigarayı bırakmış, 59 olgu $(\% 16)$ sigarayı azaltmış, 2 olgu $(\% 0,6)$ ise artırmıştı. Sigarayı bırakanların hiçbiri ilk görüşmede bırakmayı düşündüğunü söyleyenler veya daha önce bırakmayı deneyenlerden değildi. Sigarayı bırakanların yaş ortalaması sigara içmeye devam edenlere göre daha yüksekti $(p=0,044)$ ve sigarayı bırakanların daha uzun süredir sigara içme öyküleri vardı $(p=0,001)$. Hemoptizi ve çomak parmak semptomlarının varlığı sigara bırakma oranlarını anlamlı düzeyde artırmaktaydı (sırasıyla $\mathrm{p}=0,048, \mathrm{p}=0,013)$. Bu çalışmada akciğer kanseri semptom sorgulamasından 6 ay sonraki sigara bırakma oranı $(\% 4,8)$, kendiliğinden sigarayı bırakma oranından $(\% 1)$ anlamlı düzeyde yüksekti $(\mathrm{p}=0,001)$.

Sonuç: Akciğer kanseri semptom taramasıyla sigara bırakma oranları artırılabilir. Sigara bırakma poliklinikleri yanında bu tip yaklaşımlar sigara mücadelesine katkıda bulunabilir.

Anahtar Kelimeler: Sigara bırakma; akciğer kanseri; kanser tarama; hemoptizi; çomak parmak

\section{ABSTRACT}

\section{The Role of Lung Cancer Symptom Screening in Smoking Cessation}

Aim: In this study, the role of lung cancer symptom screening in smokers aged 30 and over in Duzce city was investigated.

Materials and Methods: 500 cases over 30 years of age with a smoking history randomly selected from 700 households were included in the study. The smoking habits and symptoms of lung cancer cases were evaluated by a questionnaire with a face to face manner. It was emphasized that smoking is an important risk factor for lung cancer. Smoking habits were re-questioned by phone in 353 of 474 active smokers 6 months later.

Results: Of the 353 smokers, 32 (9.1\%) were female and $321(90.9 \%)$ were male. It consisted of cases with a mean age of $46 \pm 9$ and an average of $36 \pm 24$ pack/year smoking history. 130 cases $(\% 36.8)$ were intended to smoking cessation and $65(\% 18,4)$ had tried smoking cessation. In the 6 months follow-up $17(\% 4.8)$ of them had given up smoking, 59 $(\% 16)$ of them had decreased, and $2(\% 0,6)$ of them had increased it. The cases who had given up smoking were not the ones who had an intention to smoking cessation and had tried to quit at the first interview. Those who quit smoking had a higher mean age $(\mathrm{p}=0.044)$ and had a longer smoking history $(\mathrm{p}=0.001)$. The presence of hemoptysis and clubbing symptoms significantly increased smoking cessation rates $(\mathrm{p}=0.048, \mathrm{p}=0.013$, respectively). In this study, the quit rate after 6 months of lung cancer symptom questioning (4.8\%) was significantly higher than the spontaneous smoking cessation rate $(1 \%)(\mathrm{p}=0.001)$.

\footnotetext{
1Tarsus Devlet Hastanesi, Türkiye

2Düzce Üniversitesi Tıp Fakültesi Göğüs Hastalıkları Anabilim Dalı, Türkiye

3Hatay Devlet Hastanesi, Türkiye

* Çalışma Dr Reşat Yeşiloğlu'nun Uzmanlık Tezi olarak yapılmış olup Tez Danışmanı Dr Ali Nihat ANNAKKAYA dır. Türkiye Solunum Araştırmaları 2008 kongresinde ön sonuçları sunulmuştur. (Yeşiloğlu R, A. N. Annakkaya, N. Özer, N. Karataş, Ö. Balbay, P. Arbak. "Akciğer Kanseri Semptom Taramasının Sigara Bıraktırmadaki Rolü". TÜSAD 30. Ulusal Kongre, Kongre kitabı, Cilt 10, 27s, Bodrum 2008)

Sorumlu Yazar / Corresponding Author: Ali Nihat Annakkaya, e-mail: annakkaya@gmail.com

Geliş Tarihi / Received: 12.04.2021, Kabul Tarihi / Accepted: 12.10.2021
} 
Conclusion: Smoking cessation rates can be increased by screening for lung cancer symptoms. Along with smoking cessation outpatient clinics, such approaches can contribute to the fight against smoking.

Keywords: Smoking cessation; lung cancer; cancer screening; hemoptysis; clubbing

\section{GİRIŞ}

Sigara kullanımı ile ciddi ve ölümcül pek çok hastalık arasında ilişkilerin ortaya konmasından sonra sigara kullanımının kontrolü için çalışmalar başlatılmıştır. Sigara alışkanlığını hiç edinmemek en etkili ve yararlı yöntem olmakla beraber, sigara içmekte olanların bu davranışlarından vazgeçmelerini sağlamak üzere de çaba gösterilmesi önemlidir.

Dünya genelinde 1,2 milyar insanın sigara içtiği ve bu sayının 2025 yılında 1,6 milyara yükselmesi beklenmektedir (1). Her yıl sigaraya bağlı hastalıklar nedeniyle beş milyon kişinin yaşamını yitirdiği, bugünkü sigara içme oranları devam ederse, bugün hayatta olan 500 milyon kişinin sigaraya bağlı nedenlerden öleceği düşünülmektedir (2). Ülkemizde ise yaklaşı 17 milyon kişinin sigara içtiği, sigaraya bağlı hastalıklar nedeniyle her yıl yaklaşık 100.000 kişinin yaşamını yitirdiği, bu sayının 2035 yılında 240.000'e yükseleceği beklenmektedir (3).

Sigara dünyanın birçok gelişmiş ve gelişmekte olan ülkelerinde olduğu gibi ülkemizde de önemli bir sağlık sorunudur. Ülkemizde 1988 yılında yapılan ve tüm ülkeyi temsil eden bir araştırmaya göre 15 yaş ve üstü erkeklerin $\% 62,8$ 'i, kadınların \%24,3'ü tüm nüfusun ise \%43.6's1 sigara içmektedir (4). Sigara önlenebilir hastalıkların ve ölümlerin başlıca nedenidir (1). Sigara tüketimi gelişmiş ülkelerde azalırken gelişmekte olan ülkelerde artmaya devam etmektedir (5).

Her yıl sigara içenlerin \%70’i bırakmayı düşünmekte, 1/3'ü de bırakmayı denemektedir. Fakat kendi başına deneyenlerin \%98'i sonraki bir y1l içinde yeniden sigaraya başlamaktadır (6). Sigara içinde mevcut olan nikotinin merkezi sinir sistemi üzerine nöroregulatuar, biyokimyasal ve psikolojik etkileri vardır. $\mathrm{Bu}$ nedenle nikotin tekrar kullanımı yönünde istek oluşturur.

Günümüzde artık tedavi edilmesi gereken bir hastalık olarak kabul edilen sigara alışkanlığının bırakılması üzerine etkili tedavi yaklaşımlarından biri farmakoterapi, diğeri ise bilişsel-davranışçı yaklaşımlarla motivasyondan oluşan destek tedavisidir. Her iki tedavi yaklaşımı da başarı oranlarını önemli ölçüde artırmaktadır (7). Hekimin hastasına bir kez bile sigarayı bırakmayı tavsiye etmesi, hastaların \%3-5'inin sigarayı birakmasını sağlamaktadır (8).

$\mathrm{Bu}$ nedenle, klinik pratikte, uzmanlık alanı ne olursa olsun tüm sağlık görevlileri, hastalarının sigara kullanımlarını sorgulamalı ve bırakmaya teşvik etmelidirler.

Sigara içiminde; davranış alışkanlığı, fizik ve psikolojik bağımlılık rol oynamaktadır. Sigaranın bırakılmasına yardımcı olmak için birçok yöntem geliştirilmiştir. Bunların başlıcalarından biri olan davranış yöntemi; hasta eğitimi, bireysel yada grup terapileri, ters güdülenme ve tiksindirme, psikoterapi, transendental meditasyon, hipnoz, akupunktur, desensitizasyon ve duygusal deprivasyonu içerir. Akciğer hastalıkları tanısal testlerinin sigara içme davranışı üzerine etkisini araştıran çalışmalar, bu testlerin sigara bırakma motivasyonunu artırdıklarını göstermişlerdir $(9,10)$. Tarama yöntemleri sigara birakma motivasyonu artırarak sigara birakmada etkili olabilmektedir. Bu yöntemlerde kullanılan akciğer grafisi, solunum fonksiyon testi (SFT) ve bilgisayarlı tomografide saptanan anormal bulgular sigara birakma oranlarını artırmaktadır (9-12). Hasta olmak veya hasta olma kaygısı kişide sigara bırakma motivasyonunu artırmaktadır. Bu çalışmada Düzce ilinde 30 yaş ve üzeri sigara içenlerde akciğer kanseri semptom taramasının sigara bırakmadaki rolünün araştırılması amaçlandı.

\section{GEREÇ VE YÖNTEMLER Çalışma Grubu}

Düzce İli'nde, 2007 yılında, deprem sonrası yapılan, yaklaşık 31,000 kişinin yaşadığı 9000 adet kalıcı konutlarda randomize 700 hane seçilerek 30 yaş ve üstü, sigara anamnezi olan 500 olgu çalışmaya alındı.

\section{Çalışmaya dahil olma kriterleri}

Düzce ilinde 30 yaş üstü yaş grubunda bulunup, sigara anamnezi olması (aktif içici veya özgeçmişinde en az 5 paket/yıl sigara içme öyküsü).

\section{Çalışmaya Alınmama Kriterleri}

Sigara polikliniğimize başvuran, sigara bırakmaya yönelik tedavi alan, daha önce kanser hikâyesi olan, 6 ay sonra telefonla ulaşılamayacak kişiler çalışmaya alınmadı.

\section{Çalışma Düzeni}

Olguların demografik özellikleri, sigara alışkanlıkları ve akciğer kanseri semptomları (hemoptizi, kronik öksürük, göğüs ağrısı, kilo kaybı, ses kısıklığı ve çomak parmak) bir anket formuyla yüz yüze görüşmeyle sorgulandı (Tüm hastalardan bilgilendirilmiş onam formu alındi). Sigaranın akciğer kanseri için önemli bir risk faktörü olduğu vurgulandı ve bu semptomlardan en az bir tanesi olanlara Göğüs Hastalıkları poliklinik kontrolü önerildi. 500 olgunun 26 tanesi geçmişte sigarayı çeşitli yıllarda bırakmış olgulardan oluşmaktaydı. Bu olgular çalışma grubunun sigarayı kendiliğinden bırakma oranlarını hesaplamada kullanıldı. Halen aktif sigara içen 474 olgunun 353'üne 6 ay sonra telefonla ulaşılarak sigara alışkanlıkları yeniden sorguland.

Veriler anket formu ile toplandı. Anketin birinci bölümünde yaş, cinsiyet, Düzce'de oturma süresi, mesleği, telefon numarası, sigara içme durumu (kaç yıldır, günde kaç adet içiyor, bıraktı ise bırakalı ne kadar oldu) sorgulandı. Anketin ikinci bölümünde akciğer kanseri semptom sorgulaması (hemoptizi, kronik öksürük, göğüs ağrısı, kilo kaybı, ses kısıklığı ve çomak parmak) yapıldı.

Çalışma Düzce Üniversitesi Tıp Fakültesi Araştırma görevlisi tezi olarak yapılmış ve araştırma ve yayın etiğine uyulmuştur. Tip Fakültesi Girişimsel Olmayan Klinik Araştırmalar Etik Komisyonu tarafından onaylandı (Karar no: 2008/309).

\section{Tanımlamalar}

Kronik öksürük; 3 hafta veya daha uzun süre devam eden öksürük

Kilo kaybı; 12 aylık bir periyod içinde vücut ağırlığının istemsiz olarak \%5 veya daha fazlasının kaybedilmesi Hemoptizi; Sigara içtiği dönemde en az bir kez öksürükle birlikte kan gelmesi 
Göğ̈̈s ăgrısı; Travma sonrası olmayan 10 dakikadan uzun süren her türlü gögüs ağrısı

Ses kısıklı̆ğ; 1 haftadan uzun süren ses kısıklığı veya seste değişim

Çomak parmak; Hekimin muayene ile tespiti

İstatistiksel Analiz

Verilerin analizinde, SPSS 10,0 (Statistical Package for Social Sciences for Windows) programı kullanıldı. Kolmogorov-Simirnov testi ile verilerin normal dağılım değerlendirmesi yapıldı. Sigarayı birakanlar ve bırakmayanların, yaş ve sigara tüketim özelliklerinin ortalamalarının karşılaştırılmasında T test kullanıldı. Yine sigarayı birakanlar ve birakmayanların, cinsiyet ve akciğer kanseri semptomlarının karşılaştırılmasında ve çalışma grubunun kendiliğinden bırakma oranlarıyla karşılaştırmasında ki-kare testi kullanıldı. $\mathrm{p}<0,05$ değeri istatistiksel olarak anlamlılık sınırı olarak kabul edildi.

\section{BULGULAR}

Toplam 353 sigara içen olgunun 32'si $(\% 9,1)$ kadın, 321 'i $(\% 90,9)$ erkekti. Yaş ortalaması $46 \pm 9$ olan olguların, ortalama $36 \pm 24$ paket/yıl sigara anamnezi vard1. (Tablo 1).

Tablo 1. Olguların Yaş ve Sigara Kullanma Özellikleri

\begin{tabular}{|l|l|}
\hline & Ortalama \pm SS \\
\hline Yaş (yıl) & $46 \pm 9$ \\
\hline Günlük içilen sigara (adet) & $25 \pm 12$ \\
\hline Sigara kullanım süresi (yıl) & $27 \pm 10$ \\
\hline Sigara öyküsü (paket-yıl) & $36 \pm 24$ \\
\hline
\end{tabular}

SD: standart sapma;

Olguların 130'u $(\% 36,8)$ sigarayı bırakmayı düşünüyordu ve 65'i $(\% 18,4)$ sigarayı bırakmayı daha önce denemiş ancak başarılı olmamıştı.

Yapılan semptom sorgulamasında en yüksek oranda kronik öksürük ve göğüs ağrısı, en düşük oranda ise hemoptizi ve kilo kaybı gözlendi (Tablo 2).

Tablo 2. Olgularda Sorgulanan Akciğer Kanseri Semptomlarının Siklığ 1

\begin{tabular}{|l|l|l|}
\hline & Olgu Sayısı & \% \\
\hline Kronik Öksürük & 36 & 10,2 \\
\hline Göğüs Ağrısı & 28 & 7,9 \\
\hline Ses Kısıklığı & 21 & 5,9 \\
\hline Çomak Parmak & 21 & 5,9 \\
\hline Kilo Kaybı & 14 & 4,0 \\
\hline Hemoptizi & 1 & 0,3 \\
\hline
\end{tabular}

6 ay sonraki kontrolde 17 olgu $(\% 4,8)$ sigarayı bırakmış, 59 olgu (\%16) sigarayı azaltmış, 2 olgu $(\% 0,6)$ ise artırmıştı (Şekil 1). Sigarayı bırakanların hiçbiri ilk görüşmede bırakmayı düşündüğünü söyleyenler veya daha önce bırakmayı deneyenlerden değildi.

Sigarayı bırakanların yaş ve sigara kullanım süre ortalamaları, sigara içmeye devam edenlere göre istatistiksel olarak anlamlı düzeyde daha yüksekti (p değerleri sırasıyla 0,044, 0,001) (Şekil 2 ve 3) (Tablo 3).

Tablo 3. Sigarayı Bırakan ve Bırakmayanların Yaş ve Sigara Kullanma Özelliklerinin Karşılaştırılması

\begin{tabular}{|c|l|l|l|}
\hline & $\begin{array}{l}\text { Sigara } \\
\text { İcenler }\end{array}$ & $\begin{array}{l}\text { Sigarayı } \\
\text { Birakanlar }\end{array}$ & $\boldsymbol{p}$ \\
\hline $\begin{array}{c}\text { Yaş (yıl) } \\
\text { (ortalama } \pm S S)\end{array}$ & $46 \pm 9$ & $51 \pm 10$ & $\mathbf{0 , 0 4 4}$ \\
\hline $\begin{array}{c}\text { Sigara öyküsü } \\
\text { (paket-yıl) } \\
\text { (ortalama } \pm S S)\end{array}$ & $36 \pm 25$ & $39 \pm 20$ & 0,559 \\
\hline $\begin{array}{c}\text { Sigara kullanım } \\
\text { süresi (yı1) } \\
\text { (ortalama } \pm S S \text { ) }\end{array}$ & $27 \pm 10$ & $35 \pm 12$ & $\mathbf{0 , 0 0 1}$ \\
\hline
\end{tabular}

SD: standart sapma

Cinsiyet ve semptomlara göre sigara birakma oranları karşılaştırıldığında erkekler ve kadınlar arasında bırakma oranları benzer bulundu (Tablo 4). Kronik öksürük yakınması sigara bırakma oranlarını etkilemiyordu. Göğüs ağrısı, ses kısıklığı ve kilo kaybı semptomları ile sigara bırakma oranları arasında anlamlı bir ilişki bulunmadi. Hemoptizi veya çomak parmak semptomlarının olması sigara birakma oranlarını istatistiksel açıdan anlamlı olarak artırmaktaydı (sırasıyla $\mathrm{p}=0,048, \mathrm{p}=0,013$ ). Bu semptomlardan herhangi birinin olması durumunda hiç semptom olmamasına göre 2 kat fazla sigara bırakma oranı gözlendi. Aradaki fark istatistiksel anlamlı değildi (Tablo 4).

Tablo 4. Cinsiyet ve Semptomlara Göre Birakma Oranlarının Karşılaştırılması

\begin{tabular}{|c|c|c|c|c|}
\hline & İçenler & \multicolumn{2}{|c|}{ Birakanlar } & \\
\hline & $\%$ & $\mathbf{N}$ & $\%$ & \\
\hline $\begin{array}{l}\text { Cinsiyet } \\
\text { Erkek }(n=321) \\
\operatorname{Kadin}(n=32)\end{array}$ & $\begin{array}{ll}305 & (95,0) \\
31 & (96,9) \\
\end{array}$ & $\begin{array}{l}16 \\
1\end{array}$ & $\begin{array}{l}(5,0) \\
(3,1)\end{array}$ & 1,000 \\
\hline $\begin{array}{l}\text { Kronik Öksürü̈k } \\
\operatorname{Yok}(n=317) \\
\operatorname{Var}(n=36)\end{array}$ & $\begin{array}{ll}301 & (95,0) \\
35 & (97,2) \\
\end{array}$ & $\begin{array}{l}16 \\
1 \\
\end{array}$ & $\begin{array}{l}(5,0) \\
(2,8) \\
\end{array}$ & 1,000 \\
\hline $\begin{array}{l}\text { Göğüs Ağrısı } \\
\text { Yok }(n=325) \\
\operatorname{Var}(n=28)\end{array}$ & $\begin{array}{ll}310 & (95,4) \\
26 & (92,9) \\
\end{array}$ & $\begin{array}{l}15 \\
2 \\
\end{array}$ & $\begin{array}{l}(4,6) \\
(7,1) \\
\end{array}$ & 0,635 \\
\hline $\begin{array}{l}\text { Ses Kısıklığı } \\
\text { Yok }(n=332) \\
\operatorname{Var}(n=21) \\
\end{array}$ & $\begin{array}{ll}317 & (95,5) \\
19 & (90,5) \\
\end{array}$ & $\begin{array}{l}15 \\
2 \\
\end{array}$ & $\begin{array}{l}(4,5) \\
(9,5) \\
\end{array}$ & 0,268 \\
\hline $\begin{array}{l}\text { Çomak Parmak } \\
\text { Yok }(n=332) \\
\operatorname{Var}(n=21) \\
\end{array}$ & $\begin{array}{ll}319 & (96,1) \\
17 & (81,0) \\
\end{array}$ & $\begin{array}{l}13 \\
4 \\
\end{array}$ & $\begin{array}{r}(3,9) \\
(19,0) \\
\end{array}$ & 0,013 \\
\hline $\begin{array}{l}\text { Kilo Kaybu } \\
\text { Yok }(n=339) \\
\text { Var }(n=14) \\
\end{array}$ & $\begin{array}{ll}323 & (95,3) \\
13 & (92,9) \\
\end{array}$ & $\begin{array}{l}16 \\
1 \\
\end{array}$ & $\begin{array}{l}(4,7) \\
(7,1) \\
\end{array}$ & 0,506 \\
\hline $\begin{array}{l}\text { Hemoptizi } \\
\text { Yok }(n=352) \\
\operatorname{Var}(n=1)\end{array}$ & $\begin{array}{cc}336 & (95,5) \\
- & (-) \\
\end{array}$ & $\begin{array}{l}16 \\
1\end{array}$ & $\begin{array}{r}(4,5) \\
(100)\end{array}$ & 0,048 \\
\hline $\begin{array}{l}\text { Genel Semptom } \\
\text { durumu } \\
\text { Hiç Yok }(n=270) \\
\text { Herhangi biri var } \\
\end{array}$ & $\begin{array}{ll}260 & (96,3) \\
76 & (91,6) \\
\end{array}$ & $\begin{array}{l}10 \\
7 \\
\end{array}$ & $\begin{array}{l}(3,7) \\
(8,4)\end{array}$ & 0,086 \\
\hline
\end{tabular}

Başlangıçta sorgulanan 500 sigara anamnezli olgunun 25 'i ortalama 5 yılda sigarayı bırakmıştı (yılda ortalama 5 olgu). Çalışma grubunun yıllık spontan bırakma oranı $\% 1$ (5/500) idi. Bu çalışmada akciğer kanseri semptom 
sorgulamasından 6 ay sonraki birakma oranı $(\% 4,8)$, kendiliğinden sigarayı bırakma oranından (\%1) anlamlı olarak yüksekti $(\mathrm{p}=0,001)$

\section{TARTIŞMA}

Bu çalışmada akciğer kanseri semptom taramasıyla 6 ay sonunda toplumun y1llık kendiliğinden sigara birakma oranlarının yaklaşık 5 katı (\%4.8'e \%1) bırakma oranlarına ulaşıldı. İleri yaş, uzun süredir içici olmak ve hemoptizi, çomak parmak gibi semptomların varlığ bırakmayı motive ediyordu.

Halen nikotin bağımlılığının en uygun tedavisinin özellikle davranış terapileri ile beraber nikotin replasman tedavisi bupropion ve vareniklin şeklindeki farmakolojik yardımlar olduğu belirtilmektedir (7). Bunun yanında hekimlerin yönlendirdiği ve olguların en az 6 ay izlendiği 28 sigara biraktırma programının analizinde hekimlerin sadece hastaya sigarayı bırakmasını öğütlediği 15 programın ortalama başarısı \%5 (\%3-\%13), hekimlerin hastaya sigaranın bırakılması için yoğun destek verdiği 13 programın ortalama başarısı \%29 (\%13-\%40) olarak saptanmıştır. Hamilelerin, pulmoner ve kardiovasküler hastalığ 1 olan kişilerin hekimlerin yönlendirmesi ile sigarayı bırakma oranları diğer olgulara göre daha yüksektir. Hamilelerde bu oran \%1-35 arasında değişmektedir. Hekimlerin desteği ile sigaranın bırakılma oranının akciğer hastalarında \%10-76 (ortalama bir yıl bırakmış kalma oranı \%31,5), kalp hastalarında \%11-73 (ortalama bir yıl bırakmış kalma oranı \%43) olarak bulunmuştur (13). Ani ölüm veya yakın bir zamanda ölüm korkusu sigaranın bırakılmasında en güçlü motivatörlerdendir. Yakın zamanda miyokard infarktüsü geçirmiş olguların hekimin desteği ile sigarayı bırakma oranı \%60'a kadar yükselmektedir (14). Sigara içicilerin var olan pulmoner ve sistemik hastalıklarının sigara bırakma başarısını anlamlı olarak değiştirdiği belirtilmiştir. Bunu destekler şekilde yakın dönemde kliniğimizde yapılan çalışmada KOAH'lı olguların $\% 83,3$ 'ünün refakatçilerinin \%20'sinin, kanserlilerin $\% 76,7$ 'sinin refakatçilerinin \%10,7'sinin, astımlıların $\% 57,1$ 'inin refakatçilerinin \%25,9'unun sigarayı bıraktığ gösterildi (15).

Ostroff ve arkadaşlarının akciğer kanseri taramasının sigara davranışı üzerine etkilerini araştırdıkları ve ELCAP (Early lung cancer action program) da uyguladıkları düşük doz bilgisayarlı tomografi taraması sonucunda sigara birakma motivasyonunda artış saptadılar. Bu çalışmada 134 yüksek riskli aktif sigara içicisine düşük doz bilgisayarlı tomografi çekildikten 6 ay sonra telefonla görüşülerek sigara içme tarzını değiştirip değiştirmedikleri sorulmuş. Olguların 31 (\%23)'i sigarayı bırakmış, 35 (\%27)'i azaltmış, 64 (\%47) 'ü aynı düzeyde sürdürürken, $4 \quad(\% 2,9)$ 'ü sigarayı artırdıklarını belirtmişlerdi. Akciğer kanseri kaygısı olan ve nodül saptanan olguların bırakma oranları diğerlerine göre daha fazla bulunmuştu. ELCAP da en büyük kayg1 akciğer kanseri tarama programında filmlerin normal çıkmasına güvenerek adeta "lisanslı sigara içicisi" olarak bazı kişilerin sigara içme davranışını artırmasıydı (16). Biz bu çalışmamızda akciğer kanseri semptomlarını sorgulayarak sigarayı birakmada gerekli motivasyonu sağlamaya çalıştık. Literatürdeki kadar yüksek oranlar elde edilmese de sigarayı kendiliğinden birakmaya göre anlamlı bir artış elde edildi ve özellikle semptomu olmayanlarda sigara içme davranışında belirgin bir artış (lisanslı sigara içicisi) gerçekleşmediği gözlendi. Akciğer hastalıkları tanısal testlerinin sigara içme davranışı üzerine etkisini araştıran çalışmalarının sigara bırakma motivasyonunu artırdıkları gösterilmiştir (9).

Karbonmonoksit (CO) ölçümü, sigaranın oluşturduğu etkiyi anlamalarında hastalara yardımcı olabilecek etkili bir yol olup, sigara birakma motivasyonunu artırmaktadır. On ppm'in (parts per million) altında herhangi bir $\mathrm{CO}$ ölçümü hastanın o sırada sigara içmediğini gösteren bir belirtidir. Bir çalışmada CO monitorizasyonu gösterilen hastaların sadece sigara bırakma önerisi alan kontrol grubundan daha fazla sigara bırakma eğiliminde oldukları gösterilmiştir (17). CO monitorizasyonu sigara bırakma girişimi devam ederken izlem için önemlidir ve sigarayı biraktıktan sonra azalan CO konsantrasyonları sigara bırakmada ek motivasyon aracı olarak kullanılabilir (7).

Akciğerin sağlıklı değerlendirilmesi ve hava akımı kısıtlılığını göstermesi yönünden önemli bir teknik olan solunum fonksiyon testi (SFT) bazı çalışmalarda sigara bırakmayı artırmak için kullanılmıştır. Başarı oranları istatistiksel olarak anlamlı olmasa da spirometre yapılan grup lehine bulunmuştur (18). Benzer şekilde sigara polikliniğine başvuran ve kontrollerinde akciğer filminde patoloji görülen ve kendilerine söylenen olgularda sigara bırakma oranları anlamlı şekilde daha yüksek bulunmuştur (10).

Çalışmamızda akciğer kanseri semptomları sorgulandı. Literatürde akciğer kanserlerinde ilk semptom ve bulguların sıklığı öksürük (\% 8-75), kilo kaybı (\% 0-68), dispne (\% 3-60), göğüs ağrısı (\% 20-49), hemoptizi (\% 635) olarak verilmektedir (19). Semptomların hiçbiri akciğer kanseri için spesifik olmamakla birlikte sigaranın akciğer kanseri için önemli bir risk faktörü olduğunun vurgulanması ve bu semptomlardan en az bir tanesi olanlara Göğüs Hastalıkları poliklinik kontrolü önerilmesiyle motivasyon sağlandı. Bu çalışmada kronik öksürük dışında sorgulanan tüm semptomların literatürle uyumlu olarak bırakma oranlarını artırdığı gözlendi. Çomak parmak ve hemoptizi semptomlarının varlığında, sigarayı bırakma oranlarının istatistiksel olarak anlamlı düzeyde yüksek olduğu bulundu. Ancak hemoptizi şemptomu tüm örneklem grubunda sadece 1 kişide mevcuttu ve o kişi de sigarayı bıraktı.

Hekimin tek bir görüşmede dahi hastasına sigarayı bırakmayı tavsiye etmesinin bağımlıların \%3-5 inin sigarayı bırakmasına neden olduğu gösterilmiştir $(8,20)$. $\mathrm{Bu}$ tamamıyla bizim çalışmamızdakiyle benzer bir orandır. Ancak bu çalışmadaki bırakma oranları daha önemlidir. Çünkü burada hastanın şikayeti ile hekime başvurması değil, hekimin rasgele sigara içicilerinde şikayet sorgulaması söz konusudur.

Tütün bağımlılığı, uzun süreli ve kalıcı bırakma hedefine ulaşıncaya kadar defalarca öneri ve tedavi gerektiren kronik bir durumdur. Her yıl sigara içenlerin \%70'i bırakmayı düşünmekte, 1/3'ü de bırakmayı denemektedir. Fakat kendi başına deneyenlerin \%98'i sonraki bir y1l içinde yeniden sigaraya başlamaktadır (6). ELCAP çalışmasında Sigarayı bırakanlar arasında \%58'inin sigarayı bırakmaya ilk başta soğuk bakmakta olan olgular olduğu görülmüştür (16). Çalışmamızda olgularımızın 130'u $(\% 36,8)$ sigara birakmayı düşünüyordu ve 65'i 
$(\% 18,4)$ sigarayı bırakmayı denemişti. İlginç olarak sigarayı bırakanların hiçbiri ilk görüşmede bırakmayı düşündüğünü söyleyenler veya daha önce birakmayı deneyenlerden değildi. Bu önemli sonuç ELCAP'daki verileri ile benzerlik göstermektedir.

Gelişmiş batı ülkelerinde, erkekler ve kadınlar benzer oranda sigara içerken, Türkiye de sigara içme alışkanlığ 1 genel olarak erkeklerde daha yaygındır (21). Çalışmamıza dahil olan sigara içen olguların büyük çoğunluğunu erkekler oluşturmaktaydı. Kadın ve erkeklerde benzer oranlarda bırakma sonuçları elde edildi.

Tillgren ve ark. yaşları 16-84 arasında olan 5104 kişilik randomize çalışmalarında günlük tüketilen sigara miktarının, sigara içilen sene sayısının ve yaşın sigarayı bırakma başarısıyla ilişkili olduklarını bildirmişlerdir (22). Literatürde hem kadın hem de erkeklerde sigarayı bırakmanın yaş ile beraber arttığı raporlanmıştır (23). Çalışmamız literatürle uyumluydu; sigarayı bırakanların yaş ortalaması daha yüksekti ve daha uzun süredir sigara içme öyküleri vard1.

Ocak-Aralık 2001 tarihleri arasında Düzce Tıp Fakültesi Göğüs Hastalıkları Sigara Polikliniğine başvuran 49 olgunun 6 aylık izlemi sonunda \%22,4'ü sigarayı bırakmıştı. Erkeklerin bırakma oranı (\%32,1), kadınlardan $(\% 9,5)$ daha fazla bulunmuştu (24). Aynı bölgede yapılan bu çalışmadaki 6 aylık bırakma oranlarının göreceli olarak düşük olması, sigara polikliniklerinde uygulanan yoğun destek, medikal tedaviler ve bu olguların zaten bu amaç için gelmiş istekli olgular olması ile açıklanabilir. Bu çalışmanın sigara bırakmayı düşünmeyen, rasgele seçilen olgular üzerinde yapıldığı göz önüne alındığında \%4,8'lik bırakma oranı önem kazanmaktadır.

Çalışmanın en önemli limitasyonu toplumun sigara içme ve bırakma ile ilgili genel tutumunun yıllar içinde çeşitli sosyal, ekonomik ve siyasal durumlara göre farklılıklar gösterebilmesinden dolayı her dönemde benzer etkilerin elde edilmeyebileceği gerçeğidir.

\section{SONUÇ}

Akciğer kanseri semptom taramasıyla sigara bırakma oranları artırılabilir. Bu çalışmada doktorların poliklinik hastalarına yaptıkları telkinle benzer düzeyde sigara bırakma oranlarına ulaşılmıştır. Sigara bırakma poliklinikleri yanında bu tip çalışmalar da sigara mücadelesine katkıda bulunabilir.

Yazarların Katkıları: Fikir/Kavram: A.N.A.; Tasarım: A.N.A.; Veri Toplama ve/veya İşleme: R.Y., A.N.A., N.K.,N.K. ; Analiz ve/veya Yorum: R.Y., A.N.A, Ö.B., P.A.; Literatür Taraması: R.Y., A.N.A., N.K. ; Makale Yazımı: R.Y., A.N.A., Ö.B., P.A.

\section{KAYNAKLAR}

1. WHO report on the global tobacco epidemic, 2017. World Health Organization 2017.

2. Samet JM. Tobacco smoking: the leading cause of preventable disease worldwide. Thorac Surg Clin. 2013; 23(2):

103-12. https://doi.org/10.1016/j.thorsurg.2013.01.009.

3. Akdur R, Soydal T. Uluslalarası katılımlı üçüncü sigara ve sağllk ulusal kongresi bildirisi. Tütünsüz Yaşam Dergisi. 2006; 2: 1-3.
4. Türk Toplumunda Sigara İçme Davranışları ve Sigara İçme ve Sigara Karşıtı Kampanyalara Karşı Tutumlar. TC Sağlık Bakanlığı Raporu. PİAR. Ocak 1988.

5. Blok DJ, de Vlas SJ, van Empelen P, van Lenthe FJ. The role of smoking in social networks on smoking cessation and relapse among adults: A longitudinal study. Prev Med. 2017; 99: 105-10. https://doi.org/10.1016/j.ypmed.2017.02.012.

6. Tütün Kullanımında Global Trendler. Sigara İçmenin Sağlık Üzerindeki Sonuçları, Salgını Durdurmak. Yönetimler ve Tütün Kontrolünün Ekonomisi. Dünya Bankası Yayını. Çev. Taş Ş. İstanbul Yüce Reklam Yayım Dağıtım A.Ş; 2000: 1-28.

7. Jackson G, Bobak A, Chorlton I. Smoking cessation: A consensus statement with special reference to primary care. Int J Clin Pract. 2001; 55: 385-92.

8. Stead LF, Buitrago D, Preciado N, Sanchez G, Hartmann-Boyce J, Lancaster T. Physician advice for smoking cessation. Cochrane Database Syst Rev. 2013: $\quad 31 ; \quad 2013(5)$ : CD000165. https://doi.org/10.1002/14651858.pub4.

9. Risser NL, Belcher DW. Adding spirometry, carbon monoxide, and pulmonary symptom results to smoking cessation counseling: a randomized trial. J Gen Intern Med. 1990; 5: 16-22.

10. Balbay Ö, Annakkaya AN, Arbak P, Erbaş M, Bilgin C. Do clinic and chest X-ray findings of patients effect treatment compliance?. Proceedings of the ERS Annual Congress; 2002 Sep14-18; Sweden, 2002; 20 (38). p. 547.

11. Hepper NG, Drage CW, Davies SF, Rupp WM, LaMothe J, Schoenfelder PG, et al. Chronic obstructive pulmonary disease: a community-oriented program including professional education and screening by a voluntary health agency. Am Rev Respir Dis. 1980; 121(1): 97-104.

12. Townsend CO, Clark MM, Jett JR, Patten CA, Schroeder DR, Nirelli LM, et al. Relation between smoking cessation and receiving results from three annual spiral chest computed tomography scans for lung carcinoma screening. Cancer. 2005; 103(10): 2154-62.

13. Schwartz JL. Review and evaluation of smoking cessation methods: The United States and Canada 1978 - 1985, Public Health Service, National Cancer Institute. NIH Publication No. 87-2940, 1087.

14. Livingstone-Banks J, Relapse prevention interventions for smoking cessation. Cochrane Database of Systematic Reviews 2019, Issue 2. Art. No.: CD003999. https://doi.org/ 10.1002/14651858.CD003999.pub5.

15. Özmen K, Dumlu T, Arbak P, Balbay Ö, Annakkaya AN. Astım, KOAH ve akciğer kanseri hastalarında ve refakatçilerinde sigara alışkanlığı. Türkiye Solunum Araştırmaları Derneği 30. Ulusal Kongresi; 2008 Ekim 26-30; Bodrum, Muğla.

16. Ostroff JS, Buckshee N, Mancuso CA, Yankelevitz DF, Henschke CI. Smoking cessation following ct screening for early detection of lung cancer. Prev Med. 2001; 33(6): 613-21.

17. Jamrozik K, Vessey M, Fowler G, Wald N, Parker G,Van Vunakis H. Controlled trial of three different 
antismoking interventions in general practice. BMJ. 1984: 19; 288(6429): 1499-503.

18. Buffels J, Degryse J, Decramer M, Heyrman J. Spirometry and smoking cessation advice in general practice: A randomized clinical trial. Respir Med. 2006; 100(11): 2012-7.

19. Beckles MA, Spiro SG, Colice GL, Rudd RM. Initial Evaluation of the patient with lung cancer. Symptoms, signs, laboratory tests, and paraneoplastic syndromes. Chest. 2003; 123: 97-104.

20. European Medical Association Smoking or Health (EMASH): Guidelines on smoking cessation for general practitioners and other health professionals. Monaldi Arch Chest Dis. 1997; 52: 282-4.

21. Smoking and health: physician responsibility. A statement of the Joint Committee on Smoking and Health. American College of Chest Physicians. American Thoracic Society. Asia Pacific Society of Respirology. Canadian Thoracic Society. European Respiratory Society, and International Union Against Tuberculosis and Lung Disease. Chest. 1995; 108(4): 1118-21.

22. Tillgren P, Haglund BJ, Lundberg M, Romelsjo A. The sociodemographic pattern of tobacco cessation in the 980s: results from a panel study of living condition surveys in Sweden. $\mathrm{J}$ Epidemiol Community Health. 1996; 50: 625-30.

23. Fernandez E, Garcia M, Schiaffi A, Borras JM, Nebot M, Segura A. Smoking initiation and cessation by gender and educational level in catolina, Spain. Prev Med. 2001; 32: 218-23.

24. Balbay Ö, Annakkaya AN, Aytar G, Bilgin C. Düzce tıp fakültesi göğüs hastalıkları sigara bırakma polikliniği sonuçları. Düzce Tıp Fakültesi Derg. 2003; 3: $10-4$. 